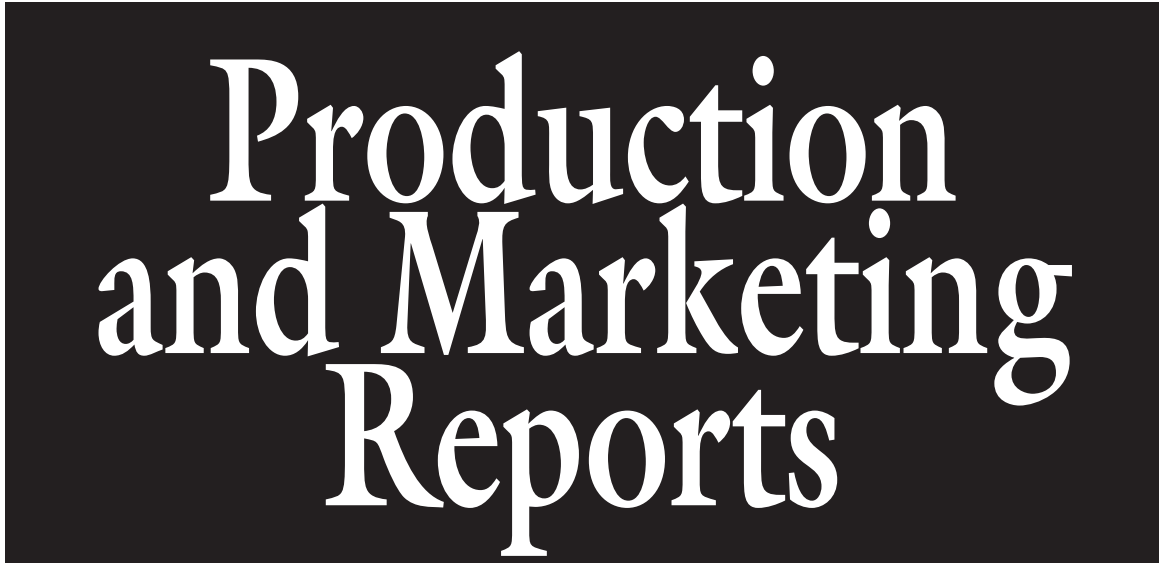

\section{Economic Contributions of the Green Industry in the United States in 2007-08}

\author{
Alan W. Hodges ${ }^{1,4}$, Charles R. Hall ${ }^{2}$, and Marco A. Palma ${ }^{3}$
}

AdDitionAl INDEX WORDs. sales, output, value added, payroll, employment, horticulture product line, production, manufacturing, landscape services, wholesale, retail trade

SUMMARY. Economic contributions of the green industry in each state of the United States were estimated for 2007-08 using regional economic multipliers, together with information on horticulture product sales, employment, and payroll reported by the U.S. Economic Census and a nursery industry survey. Total sales revenues for all sectors were $\$ 176.11$ billion, direct output was $\$ 117.40$ billion, and total output impacts, including indirect and induced regional economic multiplier effects of nonlocal output, were $\$ 175.26$ billion. The total value added impact was $\$ 107.16$ billion, including employee compensation, proprietor (business owner) income, other property income, and indirect business taxes paid to state/local and federal governments. The industry had direct employment of 1.20 million full-time and part-time jobs and total employment impacts of 1.95 million jobs in the broader economy. The largest individual industry sectors in terms of employment and value added impacts were Landscaping services ( $1,075,343$ jobs, $\$ 50.3$ billion), Nursery and greenhouse production (436,462 jobs, $\$ 27.1$ billion), and Building materials and garden equipment and supplies stores (190,839 jobs, $\$ 9.7$ billion). The top 10 individual states in terms of employment contributions were California $(257,885$ jobs), Florida (188,437 jobs), Texas (82,113 jobs), North Carolina (81,113 jobs), Ohio (79,707 jobs), Pennsylvania (75,604 jobs), New Jersey (67,993 jobs), Illinois $(67,382$ jobs), Georgia $(66,042$ jobs $)$, and Virginia $(58,677$ jobs $)$. The total value added of the U.S. green industry represented $0.76 \%$ of U.S. Gross Domestic Product (GDP) in 2007, and up to $1.60 \%$ of GDP in individual states. On the basis of a similar previous study for 2002 (Hall et al., 2006), total sales of horticultural products and services in 2007-08 increased by $3.5 \%$, and total output impacts increased by $29.2 \%$, or an average annual rate of $5.8 \%$ in inflation-adjusted terms.

$\mathrm{T}$ The U.S. environmental horticulture industry, also known as the "green industry," is comprised of wholesale nursery, greenhouse, and turfgrass sod growers; landscape service firms such as architects, designers/ builders, contractors, and maintenance firms; retail firms such as garden centers, home centers and mass merchandisers with lawn and garden departments, and marketing intermediaries such as brokers and horticultural distribution with the recession of 2008-09 (Hall, 2010). Employment in the principal sectors of the U.S. green industry grew slowly or remained stable during the period 2001-07, then dropped sharply in 2008-09, as shown in Fig. 1. Industry firms that experienced remarkable growth in sales and profits for most of this decade now face stagnant demand for product, abundant supply in the marketplace, and prospective buyers willing to purchase product only if and when needed. The housing sector collapse revealed that the rate of green industry growth was also unsustainable and current economic conditions are retarding industry recovery. In recent years, there has been considerable consolidation among large growers in response to consolidation at the retail level. The rise of large, nationwide plant retailers like home centers and mass merchandisers has created a marketing opportunity for some large growers who can supply the large volumes these customers require, and these nursery firms have grown rapidly through acquisition during the past decade to service these big customers.

Despite the size and growth of the green industry, there is surprisingly little information at the national level regarding its economic impact. The U.S. Department of Agriculture conducts floriculture and nursery crop surveys to collect information at the grower level, but only in selected states, and the cash receipts reported by growers do not reflect the further economic impacts generated from this production activity. For firms downstream in the supply chain, such as landscapers, re-wholesalers, and retailers, information may be available from state comptrollers in certain states. However, to date, no one source of data has been adequate to capture the total economic importance of the green industry nationally.

Recognizing the limitations of existing data sources and the critical need for economic impact information, numerous state nursery and landscape associations have sponsored economic impact studies for their respective states. Stakeholders have found these studies to be useful in communicating the importance of the green industry to state legislatures, in gaining assistance and resources, and in combating proposed legislation that would have negative impacts on the green industry. 
Table 1 summarizes the results of economic impact studies that have been conducted in the last 10 years regarding the green industry in selected states, with total impacts expressed on a per capita population basis, in constant 2004 dollars, and as a share of GDP by state [U.S. Department of Commerce (USDOC), 2011] to facilitate comparisons. These findings provide a benchmark for comparing the results from this study, which is national in scope. Although there have been many studies conducted to estimate grower-level sales or cash receipts, this summary only presents those studies that attempted to evaluate the postfarm gate economic impacts, including total employment and payroll associated with green industry sectors. Total output impacts estimated in these selected studies were highest for California ( $\$ 10.3$ billion), Florida ( $\$ 9.2$ billion), and Texas ( $\$ 9.0$ billion), and employment impacts in these states were 168,867 jobs, 187,859 jobs, and 222,000 jobs, respectively. For all 23 state-level studies listed, total output impacts amounted to almost $\$ 70$ billion. Per capita output impacts across all states averaged $\$ 346$ per person, and ranged from $\$ 192$ per person (Maryland), to a high of $\$ 506$ per person (Florida). Direct comparison of these results across states is complicated by differences in research methods used in these studies. For example, some states used mail or telephone surveys to collect primary data, whereas some used inperson interviews, and others relied on secondary data sources. Another important difference is the number and type of sectors that were included in each respective study, as shown in the right-hand column of Table 1. Some states included all end users such as

This research was supported in part by a grant from the Horticulture Research Institute, Washington, DC. Assistance with data analysis and writing was provided by Alba Collart of Texas A\&M University, and Tom Stevens and Mohammad Rahmani of the University of Florida. The National Nursery Survey was conducted under the auspices of the Green Industry Research Consortium, a group of Land Grant University horticulturists and economists, organized as multistate project S-1051 under USDA-NIFA.

${ }^{1}$ Food and Resource Economics Department, University of Florida, P.O. Box 110240, Gainesville, FL 32611

${ }^{2}$ Department of Horticultural Sciences, Texas A\&M University, 202 Horticulture/Forest Science Building, 2133 TAMU, College Station, TX 77843

${ }^{3}$ Department of Agricultural Economics, Texas A\&M University, 2124 TAMU, College Station, TX 77843

${ }^{4}$ Corresponding author. Email: awhodges@ufl.edu.

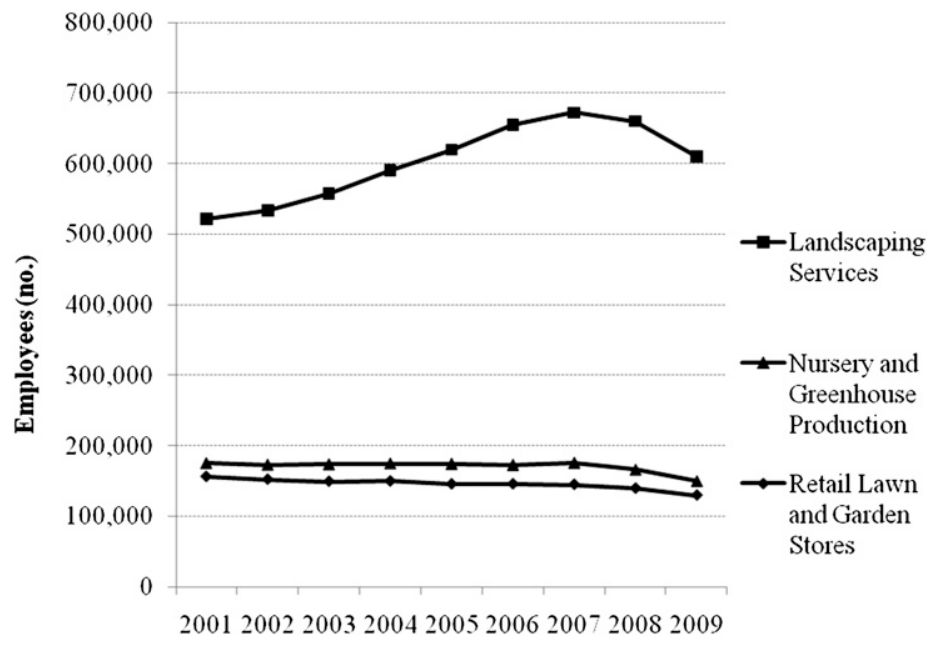

Fig. 1. Employment in principal sectors of the U.S. green industry in 2001-09 (U.S. Department of Labor, 2011).

Table 1. Summary of selected recent studies on economic contributions of the green industry in individual states.

\begin{tabular}{|c|c|c|c|c|c|}
\hline State & Yr & $\begin{array}{c}\text { Output } \\
\text { impact } \\
(\text { million } \$)\end{array}$ & $\begin{array}{l}\text { Employment } \\
\text { impact (jobs) }\end{array}$ & $\begin{array}{c}\text { Output } \\
\text { impact per } \\
\text { capita }(\$)^{z}\end{array}$ & $\begin{array}{c}\text { Sectors } \\
\text { included }^{\mathrm{y}}\end{array}$ \\
\hline Idaho & 1999 & 662 & 12,911 & 442 & $\mathrm{P}, \mathrm{L}, \mathrm{F}, \mathrm{A}, \mathrm{R}$ \\
\hline Illinois & 1999 & 3,950 & 160,000 & 276 & $\mathrm{P}, \mathrm{L}, \mathrm{R}$ \\
\hline South Carolina & 1999 & 1,380 & 24,710 & 298 & $\mathrm{P}, \mathrm{L}, \mathrm{F}, \mathrm{R}$ \\
\hline Florida & 2000 & 9,164 & 187,859 & 506 & $\mathrm{P}, \mathrm{L}, \mathrm{R}, \mathrm{T}$ \\
\hline Maryland & 2000 & 1,152 & 14,800 & 192 & $\mathrm{P}, \mathrm{L}, \mathrm{R}$ \\
\hline Pennsylvania & 2000 & 3,300 & 107,000 & 238 & $\mathrm{P}, \mathrm{L}, \mathrm{R}$ \\
\hline Tennessee & 2000 & 2,782 & 73,000 & 432 & $\mathrm{P}, \mathrm{L}, \mathrm{R}$ \\
\hline Texas & 2000 & 9,760 & 222,000 & 413 & $\mathrm{P}, \mathrm{L}, \mathrm{R}$ \\
\hline Utah & 2000 & 800 & 15,000 & 316 & $\mathrm{P}, \mathrm{L}, \mathrm{R}$ \\
\hline California & 2001 & 10,337 & 168,867 & 272 & $\mathrm{P}, \mathrm{R}$ \\
\hline Louisiana & 2001 & 2,215 & 56,686 & 450 & $\mathrm{P}, \mathrm{G}, \mathrm{L}, \mathrm{R}, \mathrm{RHA}$ \\
\hline Ohio & 2001 & 3,950 & 96,600 & 314 & $\mathrm{P}, \mathrm{L}, \mathrm{RW}, \mathrm{R}$ \\
\hline Arizona & 2002 & 1,200 & 24,100 & 203 & $\mathrm{P}, \mathrm{L}$ \\
\hline Colorado & 2002 & 1,500 & 45,000 & 307 & $\mathrm{P}, \mathrm{L}, \mathrm{G}, \mathrm{F}, \mathrm{BG}, \mathrm{R}$ \\
\hline Minnesota & 2002 & 2,110 & 28,200 & 387 & $\mathrm{P}, \mathrm{L}, \mathrm{R}$ \\
\hline Nevada & 2002 & 751 & 15,736 & 319 & $\mathrm{P}, \mathrm{RW}, \mathrm{L}, \mathrm{G}$ \\
\hline Wisconsin & 2002 & 2,706 & 43,000 & 458 & $\mathrm{P}, \mathrm{HH}, \mathrm{PG}, \mathrm{G}$ \\
\hline Connecticut & 2003 & 949 & 41,000 & 258 & $\mathrm{P}, \mathrm{L}, \mathrm{R}$ \\
\hline Maine & 2003 & 286 & 10,000 & 207 & $\mathrm{P}, \mathrm{L}, \mathrm{R}$ \\
\hline Massachusetts & 2003 & 1,860 & 52,000 & 271 & $\mathrm{P}, \mathrm{L}, \mathrm{R}$ \\
\hline New Hampshire & 2003 & 438 & 12,100 & 322 & $\mathrm{P}, \mathrm{L}, \mathrm{R}$ \\
\hline Rhode Island & 2003 & 329 & 10,000 & 289 & $\mathrm{P}, \mathrm{L}, \mathrm{R}$ \\
\hline Vermont & 2003 & 186 & 5,400 & 284 & $\mathrm{P}, \mathrm{L}, \mathrm{R}$ \\
\hline North Carolina & 2005 & 4,180 & 151,982 & 482 & $\mathrm{P}, \mathrm{L}, \mathrm{R}, \mathrm{F}, \mathrm{A}$ \\
\hline Alabama & 2007 & 2,893 & 43,670 & 663 & $\mathrm{P}, \mathrm{L}, \mathrm{R}$ \\
\hline Colorado & 2007 & 1,780 & 35,000 & 398 & $\mathrm{P}, \mathrm{L}, \mathrm{F}, \mathrm{G}, \mathrm{B}, \mathrm{RHA}$ \\
\hline Total & & 70,620 & $1,656,621$ & & \\
\hline
\end{tabular}

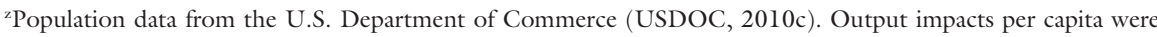
adjusted using the Gross Domestic Product implicit price deflator (USDOC, 2010d).

y $\mathrm{P}=$ Producers, $\mathrm{L}=$ Landscape-related, $\mathrm{R}=$ Retailers, $\mathrm{RW}=$ Re-wholesalers, $\mathrm{F}=$ Florists, $\mathrm{G}=\mathrm{Golf}$ courses, $\mathrm{BG}=$ Botanical gardens, $\mathrm{HH}=$ Households, $\mathrm{A}=$ Arborists, $\mathrm{T}=$ Trade firms, $\mathrm{RHA}=$ Related horticultural activities, $\mathrm{PG}=$ Public/Government.

households, golf courses, and sports complexes, while others did not. Also, the economic models used to determine economic multipliers differed between the studies, with many researchers using the Impact Analysis for Planning (IMPLAN $\AA$; MIG, Hudson, WI) input-output analysis regional 
economic modeling system, while others used the Regional InputOutput Modeling System II (RIMSII) multipliers from the USDOC, Bureau of Economic Analysis. All of these factors again point to the need to conduct a study that is national in scope that uses a common methodology to collect industry data and calculate associated economic impacts.

The first attempt to develop a national estimate of the economic impact of the green industry was reported by Hall et al. (2006, 2007). Economic impacts for the U.S. green industry in 2002 were reported as $1,964,339$ jobs, $\$ 147.8$ billion in output, $\$ 95.1$ billion in value added, $\$ 64.3$ billion in labor income, and $\$ 6.9$ billion in indirect business taxes, with these values expressed in 2004 dollars. For the production and manufacturing sectors, including nurseries/greenhouses and lawn and garden equipment manufacturers, total output impacts were $\$ 34.6$ billion, employment impacts were 300,677 jobs, and value added impacts were $\$ 20.8$ billion. For the horticultural services sectors, including landscape design, installation, and maintenance activities, total output impacts were $\$ 57.8$ billion, employment impacts were 753,557 jobs, and value added impacts were $\$ 39.0$ billion. For the wholesale/retail trade sectors, including lawn and garden stores and other wholesalers and retailers, total output impacts were $\$ 55.5$ billion, employment impacts were 910,104 jobs, and value added impacts were $\$ 35.3$ billion. The objective of this study was to update the earlier estimates of the economic impacts of the green industry at the national level, using data from primary and secondary sources.

\section{Materials and methods}

The economic sectors associated with the green industry were identified based on having horticultural products or services as their principal activity, as described in the North American Industry Classification System. In addition, wholesale and retail trade sectors that have significant sales of horticultural merchandise were included in the study. The Production and manufacturing industry group includes the sectors for Nursery and greenhouse production and Lawn and garden equipment manufacturing. The Horticultural services industry group includes the sectors Landscaping services and Landscape architectural services. The wholesale sectors within the Wholesale and retail trade group include Merchant wholesalers of durable goods such as lawnmowers and other gardening equipment, and Merchant wholesalers of nondurable goods like flowers, nursery stock, and florist supplies. Retail sectors that have product line sales of horticultural goods include Wholesale electronic markets, agents and brokers, Furniture and home furnishings stores, Electronics and appliance stores, Building material and garden equipment and supplies dealers, Food and beverage stores, Health and personal care stores, Gasoline stations, Sporting goods, hobby, book, and music stores, General merchandise stores, Miscellaneous store retailers, and Nonstore retailers. Retail lawn and garden stores are classified within the sector Building materials and garden equipment and supplies dealers, and florists are classified within Miscellaneous store retailers.

Economic information on the green industry in the United States was compiled from a variety of sources. For the nursery and greenhouse sector, national and state information on number of firms, employment, and value of sales were taken from the National Nursery Survey for 2008 conducted by the Green Industry Research Consortium, a multistate group of university economists and horticulturists (Hodges et al., 2010). For the manufacturing, horticultural services and wholesale/retail trade sectors, information on number of establishments, employment, payroll, and sales or gross receipts were taken from the 2007 Economic Census Industry Report Series for U.S. totals and from the Geographic Area Series for state-level information (USDOC, 2010a). The Economic Census is the most reliable information source available, since it has a well-established statistical methodology, with adjustment for nonresponding firms, and provides published reliability parameters. For the wholesale and retail sectors, whose primary business is not in horticulture, employment and payroll were estimated in proportion to horticulture product line sales as a share of total sales.

Data on sales of horticultural goods by the Wholesale and Retail Trade sectors were taken from the special report series on product line sales for the 2007 Economic Census
(USDOC, 2010b). Specific product lines within the retail sector category of Lawn, Garden, and Farm Equipment and Supplies included cut flowers, fertilizer-lime-chemicals-and other soil treatments, indoor potted plants and floral items, lawn and garden equipment and tools, outdoor nursery stock, and other lawn and garden equipment and supplies. Values for farm supplies and equipment were netted out of figures for retail product line sales. Product lines within the wholesale trade sectors included lawn and garden machinery, equipment and parts (durable goods), and flowers and florists' supplies (nondurable goods). For some states and sectors in which sales, employment, and payroll information were missing because of the U.S. Census Bureau's nondisclosure rules for a small number of firms, these values were imputed based on the share of total establishments, so that the sum of state values matched U.S. totals. A total of $\$ 23.5$ billion in horticultural product/ service sales were allocated in this manner.

Primary data regarding the structure and performance of the Nursery and greenhouse production sector were generated by the fifth National Nursery Survey conducted by the Green Industry Research Consortium. The survey sampled all 50 states in the United States using a standard methodology as generally described by Dillman (2007). Lists of firms in each state were compiled from the respective state departments of agriculture, resulting in a combined listing of nearly 39,000 nursery operations, from which a sample of 15,000 firms was selected for the survey. Sampling in each state was based on its proportion of the overall business population, and where possible stratified by size classes based on production area, inventory or sales volume. A total of 3044 usable responses were received from mail and telephone surveys, representing an overall response rate $15.9 \%$. On the basis of adjusted population of validated active firms $(19,803)$, total U.S. nursery industry sales were estimated at $\$ 27.14$ billion and total employment was estimated at 262,941 jobs. Further details on the survey methodology and results were reported by Hodges et al. (2010).

Information on the number of establishments, employment, payroll, and sales receipts for all sectors of the U.S. 
green industry in 2007-08 is summarized in Table 2. There were a total of 1.4 million business establishments involved in the industry, including 19,917 production or manufacturing firms, 99,930 horticultural services firms, and 1.28 million wholesale or retail trade firms. Total reported employment was 1,202,210 employees and total payroll was $\$ 35.9$ billion. Total sales revenues or receipts for horticultural products and services were $\$ 176.1$ billion, including $\$ 35.3$ billion for producers or manufacturers, $\$ \mathbf{5 8 . 3}$ billion for horticultural services, and $\$ 82.5$ billion for wholesale/retail trade.

The regional economic impacts of the green industry sectors in each state were evaluated using 2007 economic multipliers from RIMSII (USDOC, 2008). RIMSII multipliers are equivalent to IMPLAN ${ }^{\circledR}$ multipliers and are available at the state-level for a very reasonable cost. Input-output models represent the structure of a regional economy in terms of transactions between industries, employees, households, and government institutions (Miller and Blair, 2009). The RIMSII system includes over 500 distinct industry sectors, and incorporates information from the U.S. National Income and Product Accounts, together with regional economic data on commodity production, household income, employment, trade, capital investment, and taxation. The RIMSII final demand economic multipliers were used to estimate the total economic activity generated from output to final demand or exports. The multipliers capture the effects of supply chain purchases by industry firms from other economic sectors (indirect effects) and the effects of employee household consumer spending (induced effects), in addition to direct sales by industry firms. Separate multipliers were used for output (sales revenues or receipts), employment, value added, and labor income (earnings). The multipliers for output, value added, labor income, and indirect business taxes are expressed in units of dollars per dollar final demand or output, while the employment multiplier is expressed in jobs per million dollars final demand. The output total effects multipliers for each industry sector and state are shown in Table 3. Differences in values of the multipliers reflect the structure of industry sectors, the degree of economic integration, and the regional mix of supplier industries available to meet local demands. These multipliers may be considered to provide conservative estimates of the regional multiplier effects because they do not capture the interregional feedback effects intermediate input purchases.

The economic multipliers were applied to estimated industry sales or output to estimate total economic impacts using the following formula: $\mathrm{I}_{\text {hij }}=\mathrm{S}_{\mathrm{hi}} \times \mathrm{G}_{\mathrm{i}}\left[\mathrm{A}_{\text {hij }}+\mathrm{E}_{\mathrm{hi}} \times\left(\mathrm{B}_{\text {hij }}+\mathrm{C}_{\mathrm{hij}}\right)\right]$, where $\mathrm{I}_{\mathrm{hij}}$ is total impact for measures (j) of output, employment, value added, labor income, or indirect business taxes, in each sector $(\mathrm{i})$, and state $(\mathrm{h}) ; \mathrm{S}_{\mathrm{hi}}$ is industry sales in sector $\mathrm{i}$ and state $\mathrm{h}$; $\mathrm{E}_{\mathrm{hi}}$ is the proportion of industry sales exported or shipped outside the state, by sector $\mathrm{i}$ in state $\mathrm{h} ; \mathrm{A}_{\mathrm{hij}}$ is the direct effects multiplier for measure $j$ in sector $\mathrm{i}$ and state $\mathrm{h} ; \mathrm{B}_{\mathrm{hij}}$ is the indirect effects multiplier for measure $j$ in sector $\mathrm{i}$ and state $\mathrm{h} ; \mathrm{C}_{\mathrm{hij}}$ is the induced effects multiplier for measure $j$ in sector $i$ and state $h ; G_{i}$ is the gross margin on sales for sector $i$, which is set at a value of 0.201 to 0.423 for the wholesale and retail trade sectors and is set equal to 1 for the production/ manufacturing and service sectors. The calculation treats only the export portion of output as new final demand

Table 2. Number of establishments, sales revenues, payroll, and direct employment in U.S. green industry sectors in 2007-08 (Hodges et al., 2010; U.S. Department of Commerce, 2010a, 2010b)

\begin{tabular}{|c|c|c|c|c|}
\hline $\begin{array}{l}\text { Industry group/sector (North American } \\
\text { Industry Classification System no.) }\end{array}$ & $\begin{array}{c}\text { Number } \\
\text { establishments }\end{array}$ & $\begin{array}{l}\text { Sales revenues } \\
(\text { million } \$)\end{array}$ & $\begin{array}{c}\text { Payroll } \\
\text { (million } \$)\end{array}$ & $\begin{array}{c}\text { Direct } \\
\text { employment (jobs) }\end{array}$ \\
\hline Production and manufacturing & 19,917 & 35,386 & 8,773 & 277,736 \\
\hline Nursery and greenhouse production (1114) & 19,803 & 27,139 & 8,268 & 262,941 \\
\hline Lawn and garden equipment manufacturing (333112) & 114 & 8,247 & 506 & 14,795 \\
\hline Horticultural services & 99,930 & 58,276 & 19,129 & 631,511 \\
\hline Landscaping services $(56173)$ & 93,687 & 53,910 & 17,389 & 596,896 \\
\hline $\begin{array}{l}\text { Building material and garden equipment } \\
\text { and supplies stores }(444)\end{array}$ & 91,070 & 39,004 & 4,609 & 163,458 \\
\hline Miscellaneous store retailers $(453)$ & 121,911 & 7,045 & 874 & 47,175 \\
\hline Merchant wholesalers, durable goods (423) & 254,975 & 8,681 & 670 & 12,355 \\
\hline General merchandise stores (452) & 45,855 & 7,489 & 711 & 36,366 \\
\hline Merchant wholesalers, nondurable goods (424) & 134,614 & 11,568 & 470 & 9,570 \\
\hline Furniture and home furnishings stores (442) & 65,144 & 218 & 30 & 1,128 \\
\hline Gasoline stations (447) & 118,756 & 292 & 10 & 612 \\
\hline Electronics and appliance stores (443) & 50,803 & 90 & 9 & 420 \\
\hline Health and personal care stores (446) & 88,452 & 77 & 10 & 350 \\
\hline Sporting goods, hobby, book, and music stores (451) & 57,415 & 40 & 5 & 305 \\
\hline Total all industry groups & $1,399,695$ & 176,113 & 35,876 & $1,202,210$ \\
\hline
\end{tabular}

${ }^{2}$ Wholesale and retail trade sector sales, payroll, and employment reflect share of business for horticulture product lines sales. 
Table 3. Total output (revenue) multipliers for green industry sectors by state in 2007 (U.S. Department of Commerce, 2008).

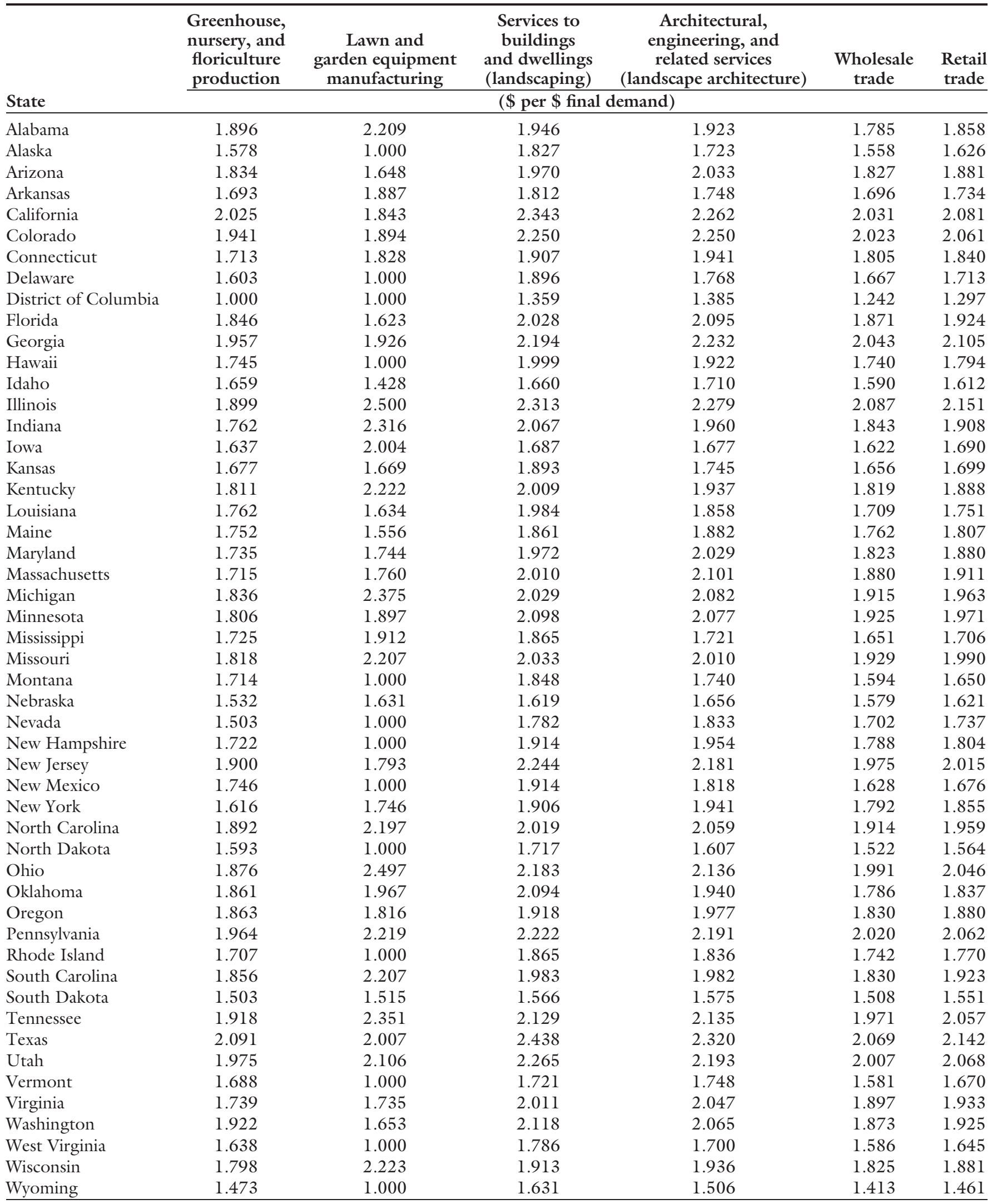

which is subject to the full multipliers effects (direct, indirect and induced), while in-state sales reflect intermediate demand from other business sectors and are subject only to the direct effects multipliers. Industry sales were taken as equivalent to output, thus assuming no net change in business inventories during the year. 


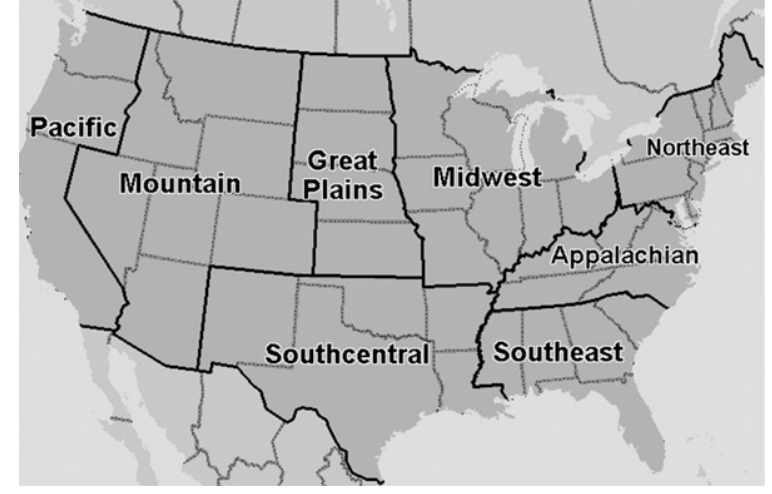

Fig. 2. Map of regions for economic analysis of the U.S. green industry. Alaska and Hawaii not shown but are included in the Pacific region.
Data on exports were taken from the IMPLAN $\AA$ database for 2002 , except in the case of the nursery and greenhouse sector, where information for some states was taken from the 2008 National Nursery Survey. The calculation for retail and wholesale sectors assumed output is reduced to reflect the gross margin on sales according to national averages taken from the Annual Benchmark Report for Retail Trade and Food Services, and the Annual Benchmark Report for Wholesale Trade (USDOC, 2005a, 2005b). The pertinent gross margins were $20.1 \%$ for flower and nursery stock wholesalers, $24.7 \%$ for general merchandise stores, $26.5 \%$ for lawn and garden

Table 4. Summary of total economic contributions of the U.S. green industry by industry group and sector in 2007-08.

\begin{tabular}{|c|c|c|c|c|c|c|c|c|}
\hline & $\begin{array}{c}\text { Sales } \\
\text { revenue }\end{array}$ & $\begin{array}{c}\text { Direct } \\
\text { output }\end{array}$ & $\begin{array}{l}\text { Total } \\
\text { output } \\
\text { impact }^{\mathrm{y}}\end{array}$ & Payroll & $\begin{array}{c}\text { Total } \\
\text { earnings } \\
\text { impact }^{\mathrm{y}}\end{array}$ & $\begin{array}{c}\text { Total value } \\
\text { added } \\
\text { impact }^{\mathrm{y}}\end{array}$ & $\begin{array}{c}\begin{array}{c}\text { Direct } \\
\text { employment }\end{array} \\
\end{array}$ & $\begin{array}{c}\text { Total } \\
\text { employmen }_{\text {impact }^{\mathrm{y}}}\end{array}$ \\
\hline $\begin{array}{l}\text { Industry group/sector } \\
\text { (North American Industry } \\
\text { Classification System no.) }\end{array}$ & \multicolumn{6}{|c|}{$($ million \$) } & \multicolumn{2}{|c|}{$\begin{array}{l}\text { (No. full-time } \\
\text { and part-time } \\
\text { jobs) }\end{array}$} \\
\hline Production and manufacturing & 35,386 & 35,386 & 52,572 & 8,773 & 13,145 & 32,128 & 277,736 & 468,692 \\
\hline $\begin{array}{l}\text { Nursery and greenhouse } \\
\text { production (1114) }\end{array}$ & 27,139 & 27,139 & 40,941 & 8,268 & 11,986 & 27,099 & 262,941 & 436,462 \\
\hline $\begin{array}{l}\text { Lawn and garden equipment } \\
\text { manufacturing (333112) }\end{array}$ & 8,247 & 8,247 & 11,632 & 506 & 1,160 & 5,028 & 14,795 & 32,230 \\
\hline Horticultural services & 58,276 & 58,276 & 92,830 & 19,129 & 30,151 & 54,521 & 631,511 & $1,123,428$ \\
\hline Landscaping services (56173) & 53,910 & 53,910 & 86,661 & 17,389 & 27,809 & 50,283 & 596,896 & $1,075,343$ \\
\hline $\begin{array}{l}\text { Landscape architectural } \\
\text { services } \mathrm{r}(54132)\end{array}$ & 4,365 & 4,365 & 6,169 & 1,740 & 2,342 & 4,238 & 34,615 & 48,085 \\
\hline Wholesale and retail trade $\mathrm{e}^{\mathrm{z}}$ & 82,452 & 23,740 & 29,856 & 7,974 & 9,866 & 20,511 & 292,962 & 357,515 \\
\hline $\begin{array}{l}\text { Building material and garden } \\
\text { equipment and supplies } \\
\text { stores }(444)\end{array}$ & 39,004 & 11,896 & 14,121 & 4,609 & 5,300 & 9,706 & 163,458 & 190,839 \\
\hline $\begin{array}{l}\text { Miscellaneous store } \\
\text { retailers }(453)\end{array}$ & 7,045 & 3,071 & 4,047 & 874 & 1,181 & 2,750 & 47,175 & 59,829 \\
\hline $\begin{array}{l}\text { Merchant wholesalers, } \\
\text { durable goods }(423)\end{array}$ & 8,681 & 2,087 & 2,985 & 670 & 945 & 2,064 & 12,355 & 19,218 \\
\hline $\begin{array}{l}\text { General merchandise } \\
\text { stores }(452)\end{array}$ & 7,489 & 1,955 & 2,220 & 711 & 794 & 1,532 & 36,366 & 39,433 \\
\hline $\begin{array}{l}\text { Merchant wholesalers, } \\
\text { nondurable goods ( } 424)\end{array}$ & 11,568 & 1,921 & 2,852 & 470 & 752 & 1,975 & 9,570 & 15,732 \\
\hline Non-store retailers $(454)$ & 3,368 & 1,455 & 1,878 & 279 & 409 & 1,278 & 7,408 & 12,170 \\
\hline Food and beverage (445) & 2,451 & 706 & 823 & 252 & 288 & 567 & 12,785 & 14,074 \\
\hline $\begin{array}{l}\text { Wholesale electronic markets, } \\
\text { agents and brokers }(425)\end{array}$ & 2,129 & 431 & 658 & 46 & 116 & 453 & 1,030 & 2,765 \\
\hline $\begin{array}{l}\text { Furniture and home } \\
\text { furnishings stores (442) }\end{array}$ & 218 & 97 & 114 & 30 & 35 & 78 & 1,128 & 1,325 \\
\hline Gasoline stations (447) & 292 & 57 & 81 & 10 & 17 & 54 & 612 & 920 \\
\hline $\begin{array}{l}\text { Electronics and appliance } \\
\text { stores }(443)\end{array}$ & 90 & 26 & 30 & 9 & 11 & 21 & 420 & 467 \\
\hline $\begin{array}{l}\text { Health and personal } \\
\text { care stores }(446)\end{array}$ & 77 & 23 & 28 & 10 & 11 & 19 & 350 & 403 \\
\hline $\begin{array}{l}\text { Sporting goods, hobby, book, } \\
\text { and music stores }(45 \mathrm{l})\end{array}$ & 40 & 15 & 18 & 5 & 6 & 12 & 305 & 339 \\
\hline Total all industries & 176,113 & 117,402 & 175,258 & 35,876 & 53,162 & 107,160 & $1,202,210$ & $1,949,635$ \\
\hline
\end{tabular}

${ }^{2}$ Values for wholesale and retail trade sectors reflect share of sales, employment and payroll for horticulture product lines, and gross margin on sales for output.

yTotal impact estimates include regional economic multiplier effects. 
Table 5. Summary of total economic contributions of the U.S. green industry in regions and states in 2007-08.

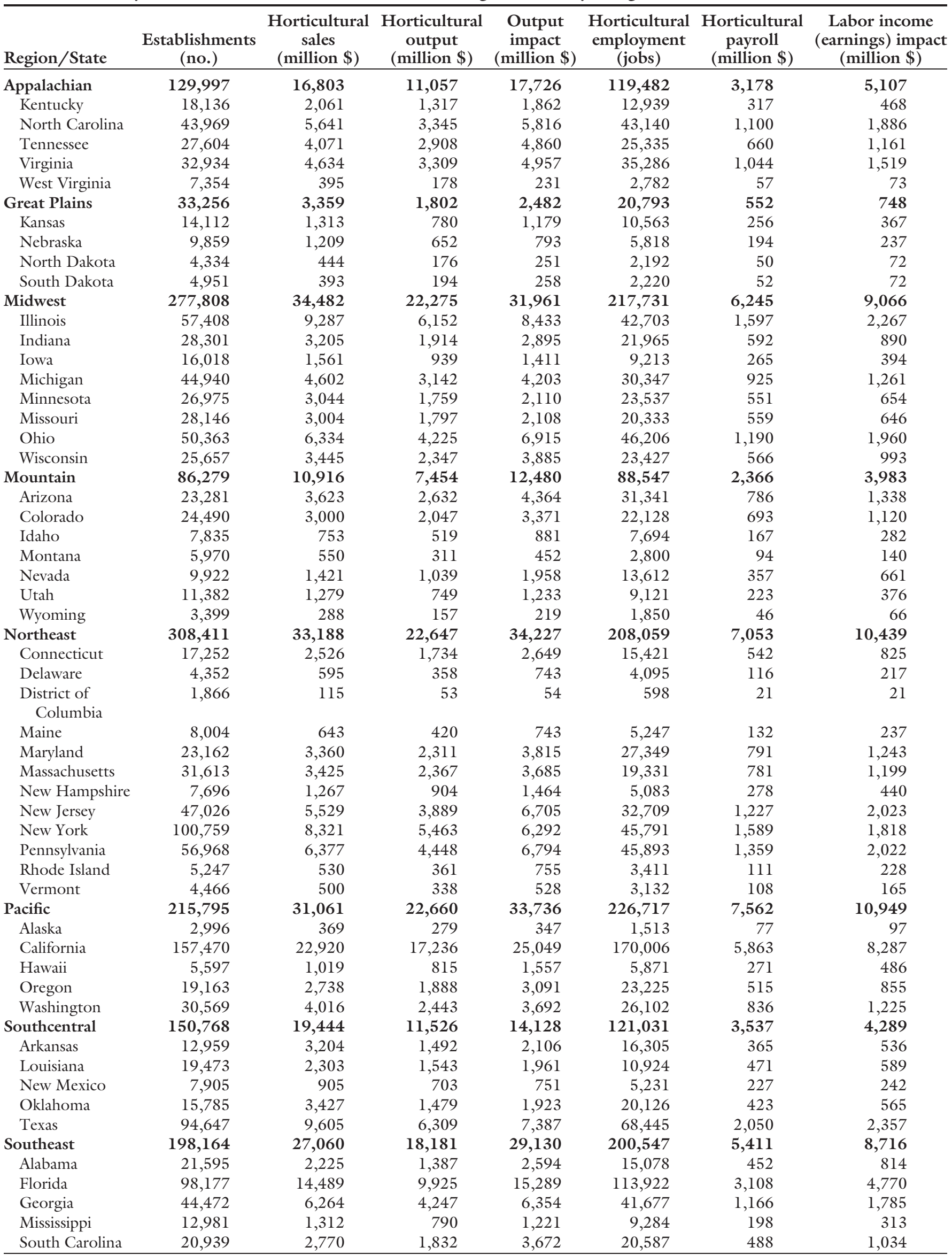


Table 6. Summary of total employment and value added contributions of the U.S. green industry in regions and states by industry group in 2007-08.

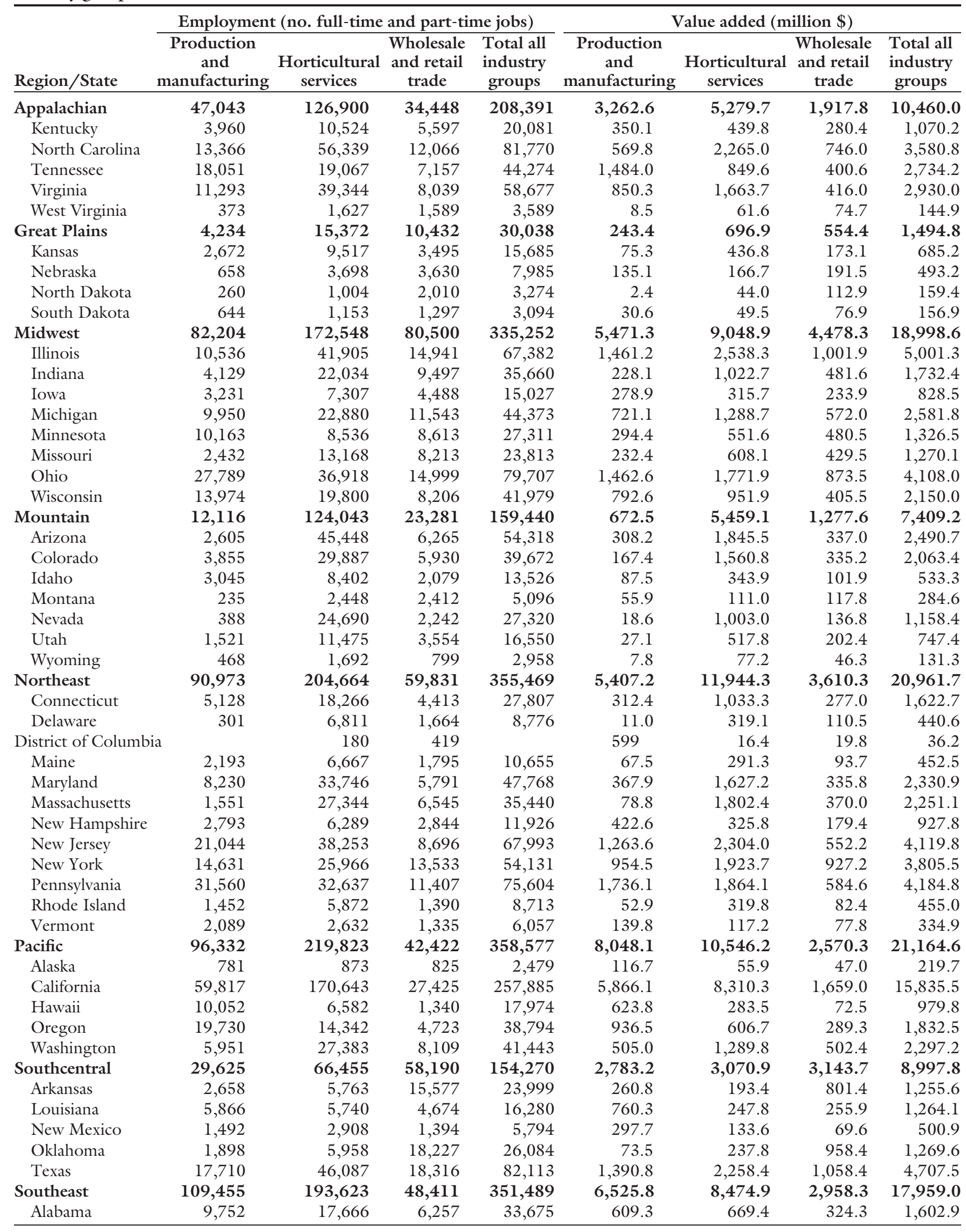


Table 6. (Continued) Summary of total employment and value added contributions of the U.S. green industry in regions and states by industry group in 2007-08.

\begin{tabular}{|c|c|c|c|c|c|c|c|c|}
\hline \multirow[b]{2}{*}{ Region/State } & \multicolumn{4}{|c|}{ Employment (no. full-time and part-time jobs) } & \multicolumn{4}{|c|}{ Value added (million \$) } \\
\hline & $\begin{array}{c}\text { Production } \\
\text { and } \\
\text { manufacturing }\end{array}$ & $\begin{array}{l}\text { Horticultural } \\
\text { services }\end{array}$ & $\begin{array}{l}\text { Wholesale } \\
\text { and retail } \\
\text { trade }\end{array}$ & $\begin{array}{c}\text { Total all } \\
\text { industry } \\
\text { groups }\end{array}$ & $\begin{array}{c}\text { Production } \\
\text { and } \\
\text { manufacturing }\end{array}$ & $\begin{array}{l}\text { Horticultural } \\
\text { services }\end{array}$ & $\begin{array}{c}\text { Wholesale } \\
\text { and retail } \\
\text { trade }\end{array}$ & $\begin{array}{c}\text { Total all } \\
\text { industry } \\
\text { groups }\end{array}$ \\
\hline Flc & 68 & 9 & 19 & 18 & 3 & $\mathrm{~T}$ & 1,3 & 9,7 \\
\hline Georgia & 18,305 & 35,004 & 12,732 & 66,042 & $1,316.9$ & $1,703.1$ & 791.4 & $3,811.4$ \\
\hline Mississippi & 5,058 & 6,613 & 3,525 & 15,197 & 273.0 & 232.0 & 184.3 & 689.2 \\
\hline
\end{tabular}

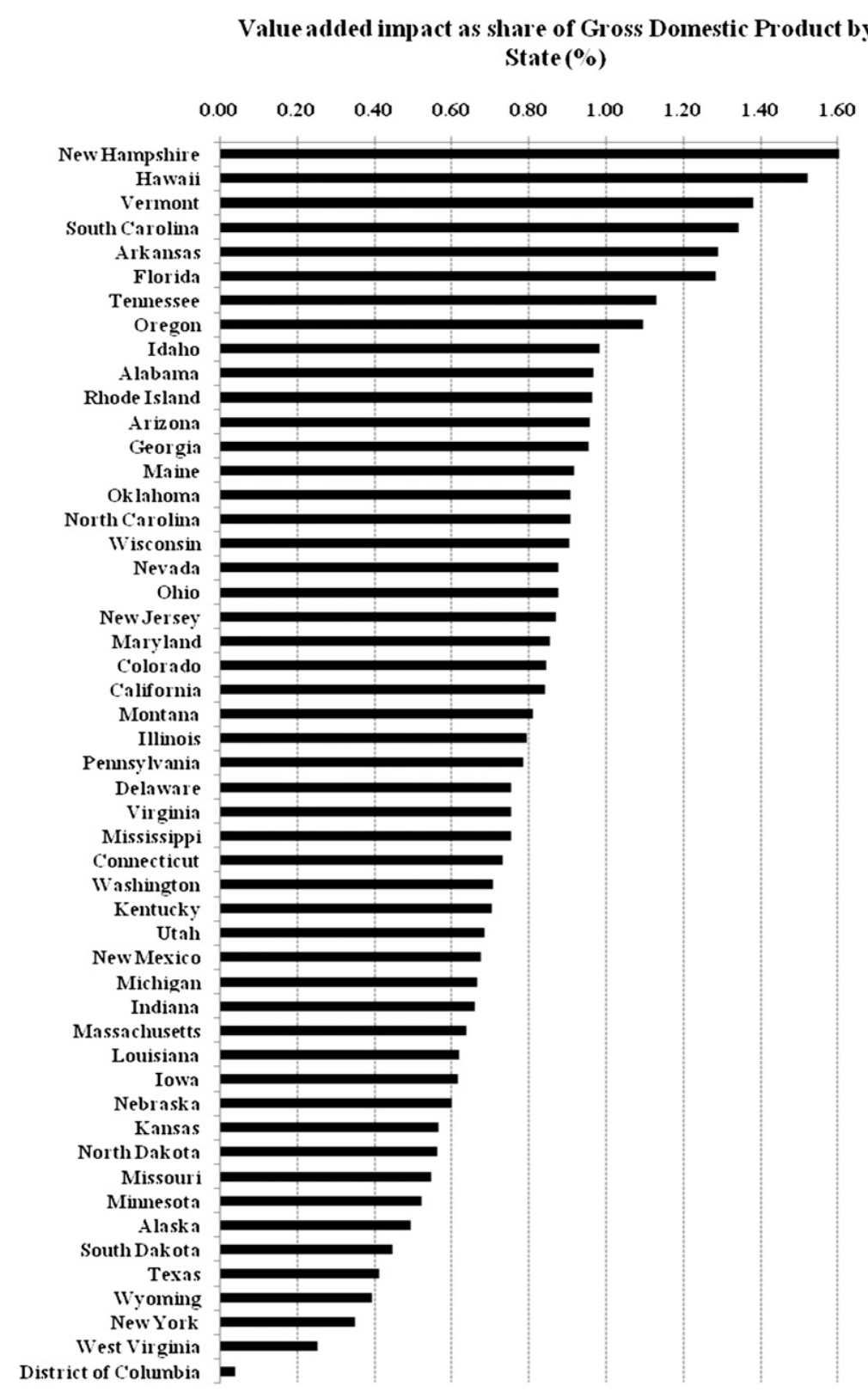

Fig. 3. Rank ordered total value added contributions by the U.S. green industry in each state as a share of Gross Domestic Product in 2007-08.

equipment wholesalers, $28.5 \%$ for food and beverage stores, $29.5 \%$ for lawn and garden stores and Building materials and supply stores, and $42.3 \%$ for florists (miscellaneous retailers). All economic data were compiled and reported for each industry sector and individual states within eight regions of the United States, as shown in Fig. 2.

\section{Results and discussion}

Economic contribution estimates for the U.S. green industry in 200708 are summarized by sector in Table 4. Total sales revenues for all sectors were \$176.11 billion, direct output was $\$ 117.40$ billion, and total output impacts, including indirect and induced regional economic multiplier effects of nonlocal output, were $\$ 175.26$ billion. Total industry payroll was $\$ 35.88$ billion and the total labor earnings impact (with multiplier effects) was \$53.16 billion. The total value added impact was \$107.16 billion, including employee compensation, proprietor (business owner) income, other property income, and indirect business taxes paid to state/local and federal governments. The industry had direct employment of 1.2 million full-time and part-time jobs, and total employment impacts of 1.95 million jobs in the broader economy.

For the Production and manufacturing industry group, including the sectors Nursery and greenhouse production and Lawn and garden equipment manufacturing, total output impacts were $\$ 52.57$ billion, employment impacts were 468,692 jobs, earnings impacts were $\$ 13.14$ billion, and value added impacts were $\$ 32.13$ billion. For the Horticultural services group consisting of Landscape services and Landscape architectural services, total output impacts were $\$ 92.83$ billion, employment impacts were $1,123,428$ jobs, earnings impacts were $\$ 30.15$ billion, and value added impacts were $\$ 54.52$ billion. For the Wholesale and retail trade group, total output impacts were $\$ 29.86$ billion, employment impacts were 357,515 jobs, earnings impacts were $\$ 9.86$ billion, and value added impacts were $\$ 20.51$ billion. 


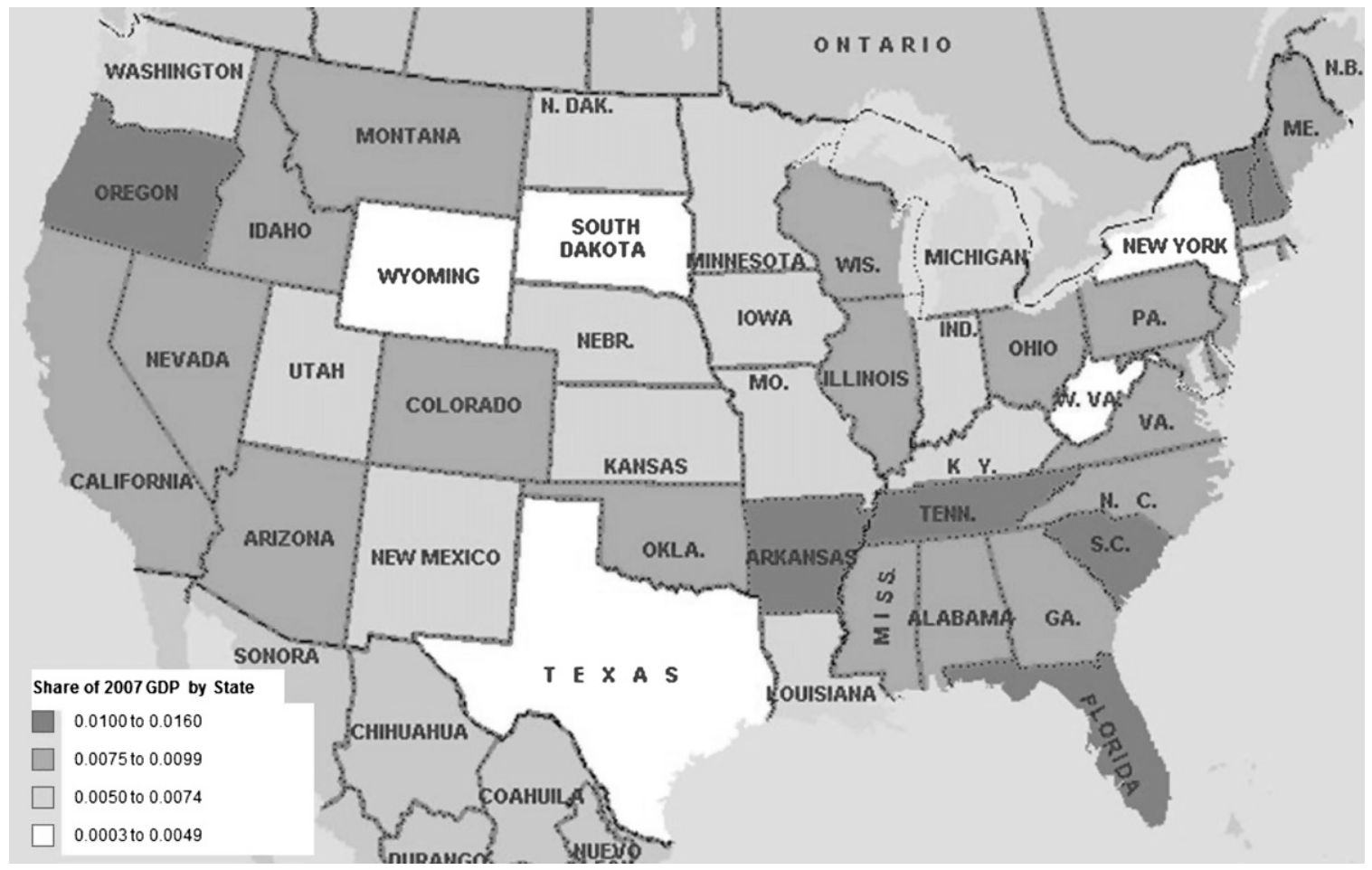

Fig. 4. Map of value added contributions by the green industry in each state as a share of Gross Domestic Product in $2007-08$. Alaska and Hawaii are not shown.

The largest individual green industry sectors in terms of employment and value added impacts were Landscaping services ( $1,075,343$ jobs, $\$ 50.3$ billion), Nursery and greenhouse production (436,462 jobs, \$27.1 billion), and Building materials and garden equipment and supplies stores $(190,839$ jobs, $\$ 9.7$ billion), as shown in Table 4. Other industry sectors with employment impacts exceeding 10,000 jobs were Miscellaneous store retailers $(59,829$ jobs $)$, Landscape architectural services $(48,085$ jobs), Lawn and garden equipment manufacturing $(32,230$ jobs), General merchandise stores (39,433 jobs), Merchant wholesalers of durable goods (19,218 jobs), Merchant wholesalers of nondurable goods $(15,732$ jobs), Food and beverage stores (14,074 jobs), and Non-store retailers $(12,170$ jobs $)$.

The economic contributions by the green industry in U.S. states and regions are summarized in Tables 5 and 6 . The largest regions in terms of total employment contributions were the Pacific ( 358,577 jobs), Southeast (351,489 jobs), and Midwest $(335,252$ jobs), followed by the Appalachian region $(208,391$ jobs), Mountain (159,440 jobs), Southcentral (154,270 jobs), and Great Plains (30,038 jobs).

Table 7. Comparison of economic impacts of the U.S. green industry in 2002-03 and 2007-08.

\begin{tabular}{lrrr}
\hline Measure & 2002-03 & 2007-08 & Change (\%) \\
\hline Horticultural sales (million \$) & 170,099 & 176,113 & 3.5 \\
Output impact (million \$) & 135,682 & 175,258 & 29.2 \\
$\quad$ Production and manufacturing & 38,419 & 52,572 & 36.8 \\
Horticultural services & 64,190 & 92,830 & 44.6 \\
$\quad$ Wholesale and retail trade & 33,073 & 29,856 & -9.7 \\
Value added impact (million \$) & 87,725 & 107,160 & 22.2 \\
Labor income impact (million \$) & 59,862 & 53,162 & -11.2 \\
Direct employment (no. jobs) & $1,235,557$ & $1,202,210$ & -2.7 \\
Employment impact (no. jobs) & $1,619,322$ & $1,949,635$ & 20.4 \\
$\quad$ Production and manufacturing & 300,677 & 468,692 & 55.9 \\
$\quad$ Horticultural services & 753,557 & $1,123,428$ & 49.1 \\
Wholesale and retail trade & 565,087 & 357,515 & -36.7 \\
\hline
\end{tabular}

${ }^{2}$ Values for 2002-03 adjusted for inflation using the U.S. Gross Domestic Product implicit price deflator (U.S Department of Commerce, 2010d).

Generally, output and value added contributions among regions followed the same ordering as employment. The top 10 individual states in terms of employment contributions were California $(257,885$ jobs $)$, Florida $(188,437$ jobs), Texas $(82,113$ jobs $)$, North Carolina $(81,113)$ jobs, Ohio $(79,707$ jobs $)$, Pennsylvania $(75,604$ jobs $)$, New Jersey $(67,993$ jobs $)$, Illinois $(67,382$ jobs), Georgia (66,042 jobs), and Virginia $(58,677$ jobs $)$.

The contribution of the green industry to GDP is a measure of the industry's importance to the overall economy. GDP is equivalent to the sum of value added by all industries and alternatively represents gross output minus intermediate purchases of goods and services from other U.S. industries or imports. The total value added of the U.S. green industry (\$107.45 billion ) represented $0.76 \%$ of U.S. GDP in 2007 ( $\$ 14,062$ billion). The contribution of the green industry to GDP by state is presented in Fig. 3, and a map of these data is shown in Fig. 4 . The top-10 states with the 
highest percentage contribution to GDP were New Hampshire (1.60\%), Hawaii (1.52\%), Vermont (1.38\%), South Carolina (1.34\%), Arkansas (1.29\%), Florida (1.31\%), Tennessee (1.13\%), Oregon (1.10\%), Idaho $(0.98 \%)$, and Alabama (0.97\%).

Changes in estimated economic impacts of the U.S. green industry from 2002-03 to 2007-08 are shown in Table 7 , with values for 2002-03 adjusted using the GDP implicit price deflator to express all values in 2007 dollars. Total horticultural sales increased by $3.5 \%$ and total output impacts increased by $29.2 \%$, or an average annual rate of $5.8 \%$ over the 5 -year period. While the Production and manufacturing industry group and Horticultural services group had substantially increased output impacts of $36.8 \%$ and $44.6 \%$, respectively, the Wholesale and retail trade group declined by $9.7 \%$ during this period. Value added impacts increased by $22.2 \%$, however, labor income impacts declined by $11.2 \%$. Direct employment also declined by $2.7 \%$ but total employment impacts increased by $20.4 \%$. The Production and manufacturing industry group had the highest increase in employment impacts $(56 \%)$, followed closely by the Horticultural services industry group (49\%). However, the Wholesale and retail trade industry group registered a decline of nearly $37 \%$ in employment impacts during the 2002-07 period. Note that these changes in economic impacts reflect changes in economic structure and integration as well as growth in industry activity. Also, the increase in sales estimated for the Nursery and greenhouse production sector in 2008 reflects the use of information from the National Nursery Survey rather than the Census of Agriculture, which was used for the previous study for 2002.

It should be kept in mind that the economic contributions reported here for the green industry in 2007 do not reflect possible decreases occurring during the recession of 2008-09. Anecdotal evidence from stakeholders suggests that industry sales declined by $10 \%$ to $40 \%$ from their peak in 2007 . Quantification of the impacts of recession on the green industry is currently an active area of research.

\section{Literature cited}

Dillman, D.A. 2007. Mail and internet surveys: The tailored design method. 2 nd ed. Wiley, Hoboken, NJ.

Hall, C.R. 2010. Making cents of green industry economics. HortTechnology 20(5):832-835.

Hall, C.R., A.W. Hodges, and J.J. Haydu. 2006. The economic impact of the green industry in the United States. HortTechnology 16(2):1-9.

Hall, C.R., A.W. Hodges, and J.J. Haydu. 2007. The economic impacts of the green industry in the United States. Southern Coop. Ser. Bul. 406.

Hodges, A.W., M.A. Palma, and C.R. Hall. 2010. Trade Flows and Marketing Practices Within the United States Nursery Industry: 2008. Southern Coop. Ser. Bul. I May 2011. <http://www.aggiehorticulture.tamu.edu/faculty/hall/ publications/scsb411.pdf $>$.

Miller, R.E. and P.D. Blair. 2009. Inputoutput analysis: Foundations and extensions. 2nd ed. Cambridge Univ. Press, New York.

MIG. 2004. Implan professional, impact analysis and social accounting software, and 50 state data package for 2002. MIG, Inc., Hudson, WI.

U.S. Department of Commerce. 2005a. Annual Benchmark Report for Retail Trade and Food Services: January 1992 through February 2005. Current Business Rpt. BR/04-A. 5 Mar. 2010. <http:// www.census.gov/prod/2005 pubs/ br04-a.pdf>.

U.S. Department of Commerce. 2005b. Annual Benchmark Report for Wholesale
Trade: January 1992 through January 2005. Current Business Rpt. BW/04-A. 5 Mar. 2010. <http://www.census.gov/ prod/2005pubs/bw05-a.pdf>.

U.S. Department of Commerce. 2008. Regional Input-Output Modeling System II (RIMSII), 2007 Economic Multiplier Reports for Selected Industries in U.S. States. 1 Oct. 2010. <https://www.bea. gov/region/rims/rimsii>.

U.S. Department of Commerce. 2010a. 2007 Economic Census, Geographic Area Series, Industry Statistics for the States, Metropolitan and Micropolitan Statistical Areas, Counties and Places: Manufacturing (EC0731Al), Wholesale Trade (EC042Al), Retail Trade (EC0744Al), Professional, scientific and technical services (EC0754Al), Administrative and support and waste management and remediation services (EC0756Al). 10 Aug. 2010. <http://www.census.gov/econ/ census07>.

U.S. Department of Commerce. 2010b. 2007 Economic Census, Subject Series, Product Line Statistics for the U.S. and States. Wholesale Trade (EC0742SLLS1) and Retail Trade (EC0744SLLS1). 10 Aug. 2010. <http://www.census.gov/econ/ census07>.

U.S. Department of Commerce. 2010c. State and County Quickfacts. 1 Feb. 2011. <quickfacts.census.gov/qfd/index. html>.

U.S. Department of Commerce. 2010d. U.S. Gross Domestic Product Implicit Price Deflator. 1 Oct. 2010. <http:// research.stlouisfed.org.fred $2 /$ data / gdpdef.txt>.

U.S. Department of Commerce. 2011. Gross Domestic Product by State. 23 Feb. 2011. <http://bea.gov/regional/gsp>.

U.S. Department of Labor. 2011. Quarterly Census of Employment and Wages. Data for All Employees and All Establishment Sizes in Selected Industries, 2001-2010. 1 Feb. 2011. <http://www. bls.gov/cew>. 